\title{
Governing Archipelagos on Their Terms: a Case Study of the Riau Islands
}

\author{
Mohamad Rachmadian Narotama ${ }^{1 *}$ \\ ${ }^{1}$ Urban and regional studies, School of geography, earth and environmental sciences, University of Birmingham, UK
}

\begin{abstract}
Indonesian geographic archipelago and its small islands' characteristics or 'Islandness' is widely known factor that shape and contour every aspect of the island life, whether it is social, economic, political, or governance. This paper addressed the pursuit of understanding the archipelago way of local government by examining how Indonesian geographic archipelago influences different aspects of island life through the experience of the archipelago governance. This paper compiled based on a 6-month research conducted in 2018 in 4 districts of the Riau Island Province; Bintan, Lingga, Natuna, and Anambas Island. This paper provided interesting findings on how geography, contours and conditions of Riau Island shape different aspects of island life and governance, in both direct and indirect ways. Although Riau Islands' government responds the situation by requesting more substantial autonomy and resource, which can contribute to more opportunities for the island development, the government misses the point of having a comprehensive way to govern the island that encompasses every aspect of governance; from public administration to political arrangements.
\end{abstract}

\section{Introduction}

The government of Riau Islands Province along with other archipelago province governments have long been negotiating with the central government for more resources and autonomy to overcome their peripherality; additional resources and autonomy is assumed to support better archipelago governance. However, when talking about archipelago governance, what exactly does it imply? We first need to take a note that small islands which become building blocks of archipelagos arguably have distinct characteristics that differentiate islands from other places; for those involved in island studies, this difference is refer as islandness [1]. Islandness and smallness can shape, contour and influence aspects of island life: social, economic, political [1]-[6].

In terms of development and governance, isolation, remoteness and peripherality become prominently highlighted attributes associated with islandness [7][12]; this relates with a broader context of discussions on the 'spatial poverty trap,' which refers to the condition where an area's development limited by the lack of certain geographical advantages such as resource, access, and population [13]. Due to their particular conditions, special attention has often been given to small island territories. Some examples include the UN's acknowledged program called Small Islands Developing States (SIDS), and various programs and arrangements have been made for remote islands. Another example of development program is Japanese remote island development program (RIDA), which is a dedicated development program for remote islands
[14]-[19]. Many islands also have special autonomy, such as Madeira and Azores (Portugal), Isle of Man and Isle of Jersey (UK), British Overseas Territories of small islands, and Okinawa (Japan). In the Island Studies, the term Sub-national island jurisdiction (SNIJ) created to refer to special arrangements small islands have, including more significant autonomy, additional resources, etc [20]-[22].

While small islands have concern over development due to their islandness, the issue of governing islands for the sake of the islanders is not a simple matter. Small islands' geography is also often intertwined with the interests of external stakeholders that hold significant influence (state, international organizations, global powers). The limelight is often given to the small islands when discussing the Anthropocene: where small islands are not only seen as of the most prominent victim of global warming but also as the ideal place to experiment on sustainable and resilience initiatives, including marine and island conservation and protection of island ecology [23]-[25].

In some cases, the extent of future-proofing small islands by emphasizing sustainability issues overshadow the current needs of the islanders; such occurrence is known as 'blue grabbing' [26]. In Indonesia, the regulations on small islands mainly focus on conservation, while the development of small islands does not become a comprehensive action; instead it is left to other general actions for rural and marginal areas, despite having unique geographies that need special attention. Another interest of influential stakeholders towards small islands relates to their function in

\footnotetext{
* Corresponding author: author@email.org
} 
geopolitics; islands are important delineators of EEZ, and often become strategic military bases.

While acknowledging the importance of islandness and balancing internal-external interests in small islands' development, we also need to emphasize 'archipelago' not just as a physical cluster of islands, but as islands that are related to one another in overlapping social, economic, political networks. Regarding governance, it is essential to acknowledge that archipelagos are as much as a socio-politically envisioned unity of islands, as much as it is a physical cluster of islands [27]; thus, relationality is at the heart of any archipelagic discussions. How then ideal archipelago governance should look like? This paper aimed to contribute to the discussions of archipelago governance by examining the relations between archipelago as a geographic entity as well as a relational network with everyday governance through the eyes of those who are involved in the governance process. Riau Islands Province used as a case study in which these examinations conducted. This paper is a breakthrough because there has not yet been extensive research on the relation of island geography and islandness influence local governance.

\section{Method}

This paper is part of the author's doctoral research project looking into the relations between island geographies, governance relations, and peripherality. This paper specifically focuses on the influence of island geography on governance practice. The research uses a qualitative research method, with semi-structured interviews with purposive sampling. The fieldwork was conducted from February to August 2018 in the following districts: Bintan, Lingga, Natuna, and Anambas Island, all are located in the Riau Islands Province.

\section{Research and Discussion}

\subsection{Public Administration and Government Arrangements}

There is still much work to be done to improve local governance in general, as Indonesia's move towards decentralization was more politically motivated rather than a strategic governance decision to improve the governance mechanism. Authors have called this "decentralization in bad faith" [28] and dubbed it "democracy first, good governance later" [29]. However, throughout the Riau Islands Province, there is a clear indication that there are specific challenges or unclear directions in how to implement public administration in small island geographies. Surprisingly there is also minimal reference and academic work on public administration for small islands; this view shared with Chittoo [30] who finds only partial work on public administration of SIDS and microstates that focus on smallness, but there is little emphasis on how islandness comes into play.

\subsubsection{Organization and Prioritization}

While autonomy and funds are given to Indonesian local governments, there are certain limitations to how the autonomy and funds can be used. Local governments must have a list of departments that established and roles to carry out. Local government is also required to participate financially in central government programs or projects. A senior local government staff explained that Bintan district was left with less than $30 \%$ of the total government budget to be spread to 36 departments; Hence major development projects are almost impossible without external support. Several responders refer to the Indonesian phrase "dilepas kepalanya, tapi dipegang ekornya" translated as letting go of the head but holding on to the tail. The funding is not distributed equally among these different departments; Bintan's Department of Transportation's budget is just enough to survive with minimum programs. Almost no budget used for sea transport-related programs (studies, safety education, vessel improvement, etc.).

\subsubsection{Development planning}

Small islands are marginalized systematically in the development planning system. In Musrenbang (Musyarawah Rencana Pembangunan or Development Plan Meetings), development recommendations are prioritized and filtered at each level (village, district, province). Variables used to prioritize proposals include: the number of populations benefiting from the project, efficiency, ease of implementation, and following national and local political priorities. For everything besides political preferences, the most minor islands have no chance of being prioritized.

\subsubsection{Rigid Schedule}

Construction on islands has inevitable challenges, including the transport of materials that affect project time schedules. In the Riau Islands, the windiest season is known by the locals as Musim Utara or North (wind) season, which usually starts from around October to February. Despite having difficulty travelling during these months, local governments required to report the end of the project at the end of the year, even though projects may start at the beginning of the windy season. Local governments resolve to informal governance, sometimes making a deal with contractors even before the tender process to get a head start in transporting materials.

\subsubsection{Spatial Arrangements}

There are three main issues regarding spatial arrangements found during the research. First, archipelago governments have very little to no revenue coming from the fisheries sector. The lack of revenue is caused by most large trawlers operate above the 12-mile shoreline, beyond the marine territory of local governments; hence revenues go directly to the central government. Unlike oil and gas, local governments do 
not receive a proportionate share of marine produce. For district governments, the loss is even more significant; since 2014, district governments had absolutely no maritime jurisdiction. The Bupati (head of district) of Natuna said that the moment they step into the water, they have no power and this condition leaves local governments have dispersed territory, having no say over the seas between their islands, this might be the most problematic reality to accept as an archipelago government.

Second, the actual network of the Riau Islands extends beyond its administrative boundaries; they cross the Malacca Strait to Malaysia and Singapore, link to Jambi and West Kalimantan, some networks stretch as far as Hong Kong. Not all of these networks are formally facilitated; hence many networks operate informally, losing the opportunity to enhance the archipelago network. Informal authorities often become the alternative path to maintain archipelago networks outside the rigid and obstructive system [31]. Third, small islands fall under unique planning systems for coastal areas and small islands. Under Act No.1/2014, small islands reserved for conservation, eco-tourism, and other activities related to the sustainability agenda. However, the implementation of the Act No.1/2014 on urban islands such as Batam or soon-to-be urban islands such as Bintan is remaining unclear. There are no guidelines or formal exceptions. On the other hand, mining on small islands is ubiquitous, sometimes having permits from the government. Hence, the direction of such regulations for small islands is unclear.

\subsection{Public Services and Development}

Small islands and archipelagos pose extreme challenges for public service delivery and development due to having dispersed populations separated by sea. However, this paper looks closer and examines how islandness also has indirect effects.

\subsubsection{Safety of Travel}

The remoteness of the small island is not the only factor that makes it hard to attract professional worker in health and education sector; another factor is the safety of travel. Those willing to work on small islands also risk their lives; inter-island transport is mostly informal using wooden motorized known as pompon, with little life-saving equipment. A person working as a village development assistant explained that some of his friends resigned from their work as they are afraid to travel, having experienced several life-threatening boat rides in rough tides.

\subsubsection{Or (Lack of) Incentive}

Although some local governments provide financial incentives for health and education professional workers to work in remote islands, working on islands can become a challenge for career upgrades. Each time a teacher needs to submit papers for an annual increase of salary, they may need to travel from an island to another island for hours to submit papers which is an expensive journey. Each time a teacher needs to leave the island, students may have to wait for several days for their teacher to return and teach again.

\subsubsection{Problematic Workplace Rotation}

Workplace Rotation of health and education professionals can be seen as a solution for remote islands. However, this is also a challenge in implementing this. A Radial hierarchy is arranged by default in the island; new staff serves in the outer-most islands while the more senior staff move towards the centre and hopefully retire in the main island. However, political elites use the archipelago geography as a medium to coerce power; those disloyal to the winning party will be punished to work at the most remote islands. The punishment also works the other way round; if somebody positioned in the remote island has a good political connection, they are able to move to the main island. Once the staff rotation to remote islands proposed, the staffs that already comfortable on the main island will try to find political support to keep their position on the main island. Meanwhile, when someone from the main land assigned to a remote island, they usually ask what they have done wrong, as the moving is associated with political exile.

\subsection{Towards an Archipelago Governance}

The findings above show that the way island ness influences government is complex, multi-faceted and multi-scalar. Understanding these relations can help construct an ideal archipelago way of governance. In general, the findings show that archipelagos need to govern on their terms, according to their needs. While autonomy is a fundamental right given by the state to local governments, the arrangements and public administrations surrounding it become an obstacle for archipelago governments to fully envision themselves as an archipelago and fulfil their ideals as a functioning archipelago. Archipelagic idea is about considering the rationality and assemblages of islands and human activities [32]. Archipelagic idea acknowledges the ontological properties of the sea between the islands [33],[35], which in practice means looking carefully in more detail and appreciating existing networks and intrinsic values of the sea and islands in the eyes of those inhabiting the archipelago. Thus, in the spirit of embodying an archipelago idea and reflecting on the findings above, several ideas or suggestions to improve current governance practice are as follows:

a. Acknowledging the unity of land and sea should be the highest priority for an archipelago government. Unlike those living on continents or large islands, for those in small island archipelagos, the sea and ocean has a presence in everyday life; described as aqua pelagic society by Hayward (2015). Hence, it would be odd to separate the sea from archipelago governance. Local governments are not satisfied that they have no control over the waters between 
their islands. In this case, the district governments and the Riau Islands Province governments should at least have proportionate revenue sharing from fishery within their seas. Archipelago governments should be encouraged to sustainably manage their marine resource and develop its marine-based economy.

b. Flexible government structure and focus on archipelago issues; an archipelago government should be allowed to determine functions that they can take, based on their geographic conditions and considering the most important roles (both internally to serve islanders and externally relating to state interests in small islands). Flexible government structure and focus on archipelago issues imply that archipelago district governments focusing more on inter-island transport improvement, public services on remote islands, and marine sustainability initiatives. Small and remote territories suggest the need for a small yet more flexible government structure by decreasing unnecessary administrative functions and increasing service providers [37]-[40].

c. Island development funds; as small islands are marginalized systematically in the development planning process, funds or programs dedicated to small islands will avoid islanders becoming marginalized. The Village Funds program shows promising implications when a similar program is designed especially for small islands. Such island funds may also be used to cover extra transport or islandness-related costs that are required for public service provision.

d. Reasonable schedule; bureaucracy, especially relating with construction projects, should allow reasonable adjustments according to the seasons.

e. Archipelago regionalism; organizational territories should not limit governance of the archipelago. Archipelagos may have networks stretching beyond administrative boundaries, while administrative limitations may occur, the spirit and understanding of archipelago governance should not be limited, and in practice, extend influence through active cooperation with surrounding governments [41], [42]. Current discussions on regions do not view regions as static places but as flows of processes, resources, and activities [43]; such views can also appropriately applied to the understanding of the archipelago region.

These suggestions will also need to be followed by efforts to improve good governance practice, especially transparency and accountability, as the dynamic nature of archipelago governance may be misused by the political elites and government staff. While there is a wide range of possibilities in the way archipelago governance may be implemented in practice, the core or essential stance that governance should acknowledge the role of islandness and the relationality of the archipelago should be held firm.

\section{Conclusion}

In summary, this paper has provided a description of some theories, concepts and current issues surrounding small islands, archipelagos and archipelago governance. This is followed by examining the case study of the Riau Islands Province; showing how current governance systems and arrangements are not yet suitable for the archipelago geography. This paper then offers suggestions in how to move towards ideal archipelago governance. The paper emphasizes acknowledging islandness as an ontological resource [44], the relationality of the archipelago [27], while facilitating small islands' unique socio-economic relations and conforming to increasing global concern over sustainability issues [14], [20]. As the archipelago province governments continuously negotiate more autonomy and resource, this paper provides a broader range of options to improve archipelago governance; some of which has nothing to do with additional resource, but adjustments in governance arrangements. The continuous discussions of archipelago governance at the local scale are crucial, as it can become a model or a test case for the more extensive Indonesian archipelago.

\section{References}

1. A. Grydehøj, Journal of Marine and Island Cultures 7, 1 (2018).

2. D. Anckar, Island Studies Journal 1, 43 (2006).

3. E. K. Stuart, Masters Abstracts International (2009).

4. P. Conkling, The Geographical Review 97, 191 (2007).

5. C. M. Hall, Tourism Recreation Research (2015).

6. E. Stratford, Political Geography 27, 160 (2008).

7. S. Williams, Environment and Planning D: Society and Space (2010).

8. W. Veenendaal, Area 52, 30 (2020).

9. P. Selwyn, World Development 8, 945 (1980).

10. A. Grydehøj and M. Casagrande, Area 52, 56 (2020).

11. A. Grydehøj and M. Casagrande, Area 52, 56 (2020).

12. G. Bocco, Geoforum 77, 178 (2016).

13. K. Bird, K. Higgins, and D. Harris, Spatial Poverty Traps An Overview Results of ODI Research Presented in Preliminary Form for Discussion and Critical Comment (London, 2010).

14. H. Kakazu, Journal of Marine and Island Cultures 7, 1 (2018).

15. L. Briguglio, The Development of the Japanese Remote Islands (1994).

16. S. Kuwahara, Journal of Marine and Island Cultures 1, 38 (2012).

17. H. Kakazu, Eurasia Border Review 2, 1 (2011).

18. G. Baldacchino and I. Kelman, Shima: The International Journal of Research into Island Cultures 8, 1 (2014).

19. UN-OHRLLS, Small Island Developing States: Small Islands Big (Ger) Stakes (United Nations, New York, 2011). 
20. A. Grydehøj, Space and Polity 15, 183 (2011).

21. S.-P. Kim, Island Studies Journal 15, 169 (2020).

22. G. Baldacchino and D. Milne, The Round Table 95, 487 (2006).

23. D. Chandler and J. Pugh, Area 52, 65 (2020).

24. V. Larjosto, Area 52, 38 (2020).

25. J. Pugh, Island Studies Journal 13, (2018).

26. A. Hill, Geoforum 79, 97 (2017).

27. E. Stratford, G. Baldacchino, E. Mcmahon, and A. Harwood, Envisioning the Archipelago (2011).

28. N. Long, Being Malay in Indonesia (NUS Press, Singapore, 2013).

29. D. E. Ramage, INDONESIA: Democracy First, Good Governance Later (2007).

30. H. B. Chittoo, Type: Double Blind Peer Reviewed International Research Journal Publisher: Global Journals Inc 11, (2011).

31. A. Grydehøj and N. Nurdin, GeoJournal (2015).

32. E. Stratford, The Idea of the Archipelago: Contemplating Island Relations (2013).

33. E. Deloughrey, Comparative Literature 69, 32 (2017).

34. E. Deloughrey, English Language Notes 57, 21 (2019).

35. P. Steinberg and K. Peters, Environment and Planning D: Society and Space 33, 247 (2015).

36. P. Hayward, The Aquapelago and the Estuarine City: Reflections on Manhattan (2015).

37. B. Dollery, J. Wallis, and A. Akimov, Local Government Studies2 36, 21 (2010).

38. H. Kitchen and E. Slack, SECOND DRAFT Providing Public Services in Remote Areas (2001).

39. M. E. Warner, Does Local Government Size Matter? Privatization and Hybrid Systems of Local Service Delivery (Atlanta, Georgia, 2012).

40. M. Vasstrøm and R. Normann, (2019).

41. G. Carbone, Expert Analysis on Geographical Specificities Mountains, Islands and Sparsely Populated Areas (2018).

42. ESPON, Territorial Cooperation for the Future of Europe (2017).

43. J. Harrison and A. Growe, European Urban and Regional Studies 21, 21 (2014).

44. E. Stratford, New Zealand Geographer 72, 216 (2016). 